\title{
In Vivo analgesic activity of aqueous extract from leaves of Limoniastrum feei
}

\begin{abstract}
Aim of the study: To evaluate analgesic effect of Limoniastrum feei, a medicinal plant from the southeast of Algeria. Two doses $(25 \mathrm{mg} / \mathrm{kg}$ and $30 \mathrm{mg} / \mathrm{kg})$ of the crude aqueous extract of leaves from Limoniastrum feei were evaluated for analgesic activity using acetic acid induced writhing in mice. The two doses $(25,30 \mathrm{mg} / \mathrm{kg})$ of the extract tested were effective. The extract at the tested doses produced a percentage inhibition of the acetic acid induced abdominal constriction of (33.39 and 35.38\%), respectively. The crude extract produced a statistically significant analgesic activity comparable to the effect of standard drug ( $50 \mathrm{mg} / \mathrm{kg}$ Diclofenac). This study demonstrated the potential analgesic properties of crude aqueous extract of leaves from Limoniastrum feei.
\end{abstract}

Keywords: limoniastrum feei, plumbagenacea, medicinal plant, endemic, analgesic activity
Volume 4 Issue 3 - 2017

\begin{abstract}
Abbes Allaoui,' Nasser Belboukhari,' Khaled Sekkoum,' Abdul Manan Mat Jais, ${ }^{2}$ Lamia Seddiki, ' Abdelkrim Cheriti $^{3}$

'Bioactive Molecules and Chiral Separation Laboratory, Faculty of Exact Sciences University Tahri Mohammed Bechar, Algeria 2Department of Biomedical Sciences, Faculty of Medicine and Health Sciences University Putra Malaysia (UPM), Malaysia ${ }^{3}$ Phytochemical Organic Synthesis Laboratory, Faculty of Exact Sciences University Tahri Mohammed Bechar,Algeria
\end{abstract}

\begin{abstract}
Correspondence: Nasser Belboukhari, Bioactive Molecules and Chiral Separation Laboratory, Faculty of Exact Sciences University Tahri Mohammed Bechar, Algeria, PO Box 417 Istiklal Street Bechar 08000, Algeria,

Email belboukhari.nasser@yahoo.com
\end{abstract}

Received: December 06, 2017 | Published: December 27 2017

\section{Introduction}

Limoniastrum feei belongs to Plumbagenaceae family. It grows in the southeast of Algeria where the climate is whole and dry, cold season in winter and hot in summer. Limoniastrum feei has a height of 10-40 ft, it's possessed long leaves and flowering palms without leaves, and its flower is endured by bricking bracts with a purplish red color. Liminiastrum feei is traditionally used to treat gastric disorders, prepared by decoction in water and drinking like tea. ${ }^{1}$ The other uses of Limoniastrum feei are as an antibacterial, for treatment bronchitis and stomach infection. ${ }^{2}$ Previous phytochemical studies reported the presence of polyphenols, flavonoids, and saponins in Limoniastrum feei. ${ }^{3}$ The methanol extracts of leaves exhibited significant in-vitro antimicrobial activity. ${ }^{4}$ Limoniastrum feei also showed remarkable antioxidant, ${ }^{5}$ antibacterial and anti-fungal activity with presence of flavonoids, saponins and tannins in methanolic and aqueous extracts. ${ }^{6}$ However, to the best of our knowledge, no study has tested here analgesic activity. This present study seeks to evaluate the analgesic effect of this plant.

\section{Materials and methods}

\section{Plant material and extraction}

The plant Limoniastrum feei was collected in February 2012 in the region of Bechar city, Algeria. The leaves were dried (overnight) and grounded into powder using the grinder. Extractions were done using Soxhlet apparatus with water for aqueous extract (ALE). The duration of extraction process was around 8 hours. $^{7}$

\section{Animals}

Male and female albino Swiss mice (24-28g) were purchased from the institute "Pasteur" Algeria (El-Koba, Algiers, Algeria) and were housed in plastic cages under standard light (light on from 7.00a.m. to 7.00 p.m. $)$ and temperature $\left(22 \pm 1^{\circ} \mathrm{C}\right)$ conditions for at least 3 days before experimentation. All studies were performed in accordance with European Union Regulations for the handling and use of laboratory animals (EEC Council Directives 86/609).

\section{Analgesic activity}

Acetic acid-induced writhing test: In this study, 24 adult mices were used. The mice were randomly divided into 4 groups, each containing 6 individuals. Analgesic effect of aqueous extract of Limoniastrum feei was investigated applying 25 and $30 \mathrm{mg} / \mathrm{kg}(10 \mathrm{ml} / \mathrm{kg}$ body weight) by intraperitoneally injection in mice. ${ }^{8}$ Diclofenac $(50 \mathrm{mg} / \mathrm{kg}$; $10 \mathrm{ml} / \mathrm{kg}$ body weight) was used as positive control. ${ }^{9}$ For the negative control animals (10 $\mathrm{ml} / \mathrm{kg}$ body weight) of water was administered in the same protocol. Thirty (30) min after receiving intraperitoneally injection of the plant extracts, positive and negative control. ${ }^{10}$ Each mouse was given intraperitoneally $0.6 \%$ aqueous solution of acetic acid $\left(10 \mathrm{ml} / \mathrm{kg}\right.$ body weight). ${ }^{11}$ After $5 \mathrm{~min}$ from the injection, each animal was placed in a transparent observation cage and the number of writhes per mouse was counted for $30 \mathrm{~min} .{ }^{12}$ The writhing activity consists of a contraction of the abdominal muscles together with a stretching of the hind limbs. ${ }^{13}$ The percentage of inhibition was calculated using the following ratio:

\section{$($ control mean - treated mean $) \times 100 /$ control mean}

\section{Results and discussion}

The effect of Limoniastrum feei, extracts on acetic acid-induced writhing responses in mice is shown in Table 1. It was found that the AELF of this plant at the doses assayed caused a significant inhibition on the writhing responses induced by acetic acid when compared with control, with values ranging from 33.39 to $35.38 \%$ of inhibition, being the AELF at a dose of $30 \mathrm{mg} / \mathrm{kg}$ i.p., in this regard, the most effective. 
Nevertheless, none of the doses of screened extract reached the values obtained for diclofenac at $50 \mathrm{mg} / \mathrm{kgi}$.p. (66.61\%), the non-steroidal anti-inflammatory chosen as a reference drug. Our results showed that intra peritoneal administration of AELF of this species significantly reduced the number of mouse abdominal constriction following acetic acid, indicating analgesic activity at the doses assayed. It is known that constriction induced by acetic acid is considered to be a non-selective anti-nociceptive model since acetic acid acts indirectly by inducing the release of endogenous mediators, ${ }^{14}$ which stimulate the nociceptive neurons that are sensitive to non-steroidal antiinflammatory drugs, to narcotics and to other centrally active. ${ }^{15,16}$

Table I Effect of the aqueous extract of Limoniastrum feei (AELF) on acetic acid-induced writhing response sin mice

\begin{tabular}{llll}
\hline Treatment & $\begin{array}{l}\text { Dose } \\
(\mathbf{m g} / \mathbf{k g})\end{array}$ & Number of writhing & Inhibition (\%) \\
\hline Control & - & 92.33 & - \\
AELF & 25 & 61.5 & 33.39 \\
& 30 & 59.66 & 35.38 \\
Diclofenac & 50 & 30.83 & 66.61 \\
\hline
\end{tabular}

\section{Conclusion}

In conclusion our results clearly showed that aqueous extract of limoniastrum feei (leaves) has an anti-nociceptive potential. We suggest the plant contains interesting molecules which might activate and modulate nociceptors. This activity explain the traditional medicinal uses of this plant.

\section{Acknowledgments}

The authors are grateful to Prof N Rayan, Nadjah University Palestin.

\section{Conflict of interest}

The author declares no conflict of interest.

\section{References}

1. Cheriti A. Rapport du projet CRSTRA. Plantes Medicinales de la Region de Bechar (Ethnopharmacologie studies). CRSTRA, Bechar, Ageria; 2000 .

2. Belboukhari N, Cheriti A. Flavonoids of Limoniastrum feei. Research journal of Phytochemistry. 2007;1:74-78.

3. Rahmani S, Belboukhari N, Cheriti A. Phytochemical investigation of Bioactive Extract from Endemic Medical Plant Limoniastrum feei (GIRARD Batt) (Plumbagenaceae). Asian Journal of Chemistry. 2014;26(2):365-368.
4. Belboukhari N, Cheriti A. Antimicrobial Activity of Aerial Part Crude Extracts From Limoniastrum feei. Asian Journal of Plant Sciences. 2005;4(5):496-498.

5. Abdelhamid El-Haci I, Didi A, AtikBekkara F, et al. In vitro antioxidant activity and total phenolic contents in methanol crude extracts from the Algerian medicinal plant Limoniastrum feei. Scientific Study \& Research. 2009;4:329-336.

6. Boudermine S, Malafronte N, Bghidja N, et al. Phytochemical investigation and anti proliferative activity of Limoniastrum feei (GIRAD) BATT. Pharmacology on Line. 2014;3:141-144.

7. Topcu G, Ulubelen A. Structure elucidation of organic compounds from natural sources using 1D and 2D NMR technics. Journal of Molecular Structure. 2007;834-836:57-73.

8. Jimoh AO, Chika A, Umar MT, et al. Analgesic effects and anti-inflammatory properties of the crude methanolic extract of Schwenckia Americana linn (Solanaceae). Journal of Ethnopharmacology. 2011;137(1):543-546.

9. Ahmad NS, Waheed A, Farman M, et al. Analgesic and anti-inflammatory effects of Pistaciaextracts in mice. J Ethnopharmacol. 2010;129(2):250 253.

10. Hajhashemi V, Sajjadi SE, Heshmati M. Anti-inflammatory and analgesic properties of Heracleum essential oil and hydroalcoholic extract in animal models. Journal of ethnopharmacology. 2009;124(3):475-480.

11. Alvarenga FQ, Mota BC, Leite $\mathrm{MN}$, et al. In vivo analgesic activity, toxicity and phytochemical of the hydro alcoholic extract from the leaves of Psidium cattleianum Sabine. J Ethnopharmacol. 2013;150(1):280-284.

12. Rabanal RM, Bonkanka CX, Hernandez-Perez M, et al. Analgesic and topical anti-inflammatory activity of Hypericum canariense L. and Hypercium glandulosum Ait. Journal of Ethnopharmacology. 2004;96(3):591-596

13. Hernandez M, Rabanal RM. Analgesic and anti-inflammatory properties of Sideritis lotsyi var. Mascaensis. Phytotherapy Research. 2002;16(3):264-266.

14. Sánchez-Mateo CC, Bonkanka CX, Hernández-Pérez M, et al. Evaluation of the analgesic and topical anti-inflammatory effects of Hypericum reflexum L. Fil. Journal of Ethnopharmacology. 2006;107(1):1-6.

15. Collier HO, Dinneen LC, Johnson CA, et al. The abdominal constriction response and its suppression by analgesic drugs in the mouse. Br J Pharmacol Chemother. 1968;32(2):295-310.

16. Bighetti EJ, Hiruma-Lima CA, Gracioso JS, et al. Anti-inflammatory and anti-nociceptive effects in rodents of the essential oil of Croton cajucara Benth. J Pharm Pharmacol. 1999;51(12):1447-1453. 